УДК 338.246+664.76 (477)

DOI: $10.15673 /$ fie.v10i4.1130

Нікішина О.В.

доктор економічних наук, старший науковий співробітник

E-mail: ksenkych@gmail.com

Муратов О.M.

кандидат економічних наук, здобувач

відділ ринкових механізмів та структур

Інститут проблем ринку та економіко-екологічних досліджень НАН України

Французький бульвар, 29, м. Одеса, Україна, 65044

E-mail:omuratov45@gmail.com

\title{
ЗАХОДИ ПОДОЛАННЯ ІНСТИТУЦІЙНИХ ДИСБАЛАНСІВ ЗОВНІШНЬОЕКОНОМІЧНОЇ ІНТЕГРАЦІЇ УКРАЇНСЬКОГО РИНКУ БОРОШНОМЕЛЬНО-КРУП'ЯНОї ПРОДУКЦІї
}

У статті досліджено природу інституційних дисбалансів та практичні форми їх прояву в сфері зовнішньоекономічної інтеграції вітчизняного ринку борошномельно-круп'яної продукції. Показано трансформаційних вплив інституційних дисбалансів на розвиток ринку з акцентом на втрати доданої вартості і податкових надходжень у національному ланцюгу вартості. Обґрунтовано комплекс взаємопов'язаних заходів щодо подолання інституційних дисбалансів зовнішньоекономічної інтеграції досліджуваного ринку. Доведено необхідність зміщення акцентів у державній агропродовольчій політиці з підтримки зернотрейдерів до підтримки виробників і експортерів зернових продуктів та модернізації інститутів відповідно до даного пріоритетного напряму. На базі відтворювального методичного підходу здійснено оцінку ефективності переорієнтації експортних товаропотоків зерна й борошна, результати якої доводять необхідність інституційної модернізації напряму підтримки експорту продуктів переробки з високою доданою вартістю.

Ключові слова: інституційний дисбаланс, ринок, зовнішньоекономічна інтеграція, експорт, додана вартість, заходи держави, ланцюг вартості.

This work is licensed under a Creative Commons Attribution 4.0 International License http://creativecommons.org/licenses/by/4.0/

Постановка проблеми та її зв'язок з важливими науковими та практичними завданнями. В умовах декомпозиції експортних товарних потоків, зниження світових цін на сировинні товари відбуваються інституційні зміни в зовнішній інтеграційній політиці держави. Так, в Експортній стратегії («дорожній карті» стратегічного розвитку торгівлі) України на 2017-2021 роки [1] зазначено, що вітчизняний експорт складається переважно із сировини (70\% експорту в 2016 р.), що є свідченням неефективного використання ресурсів. Однією із стратегічних цілей розвитку торгівлі України на 2017-2021 роки визначено створення сприятливих умов, що стимулюють торгівлю та інновації для диверсифікації експорту [1]. Таким чином, сьогодні відбувається інституційно оформлена зміна фокусу зовнішньої інтеграційної політики держави 3 сировинного на переробний напрям.

До пріоритетних секторів економіки для розвитку експорту в Експортній стратегії України віднесено, зокрема, сектор харчової і переробної промисловості, який перебуває на стадії швидкого зростання. Такі сектори повинні використовувати існуючі можливості на зовнішніх ринках та продукувати складову доданої вартості [1]. Виробництво борошномельнокруп' яної продукції (далі -БКП) є проміжною ланкою між вирощуванням зерна і випуском готових продуктів із зернових культур. БКП не є готовим продуктом споживання, водночас виробництво зернових продуктів забезпечує, з одного боку, приріст доданої вартості у ринковій системі, з іншого, відповідає цільовим орієнтирам третього кластеру, який «має перспективи сприяти переробці в Україні сировини у продукцію 3 високою доданою вартістю». Відтак, завдання сприяння розвитку експорту вітчизняної борошномельнокруп'яної продукції є складовою напрямів Експортної стратегії України [1].

Аналіз останніх публікацій по проблемі. Теоретико-методологічні засади трансформації інституційного забезпечення розвитку стратегічних агропродовольчих ринків висвітлені в працях вітчизняних й іноземних учених В. В. Ліпова [2], М. Й. Маліка, О. Г. Шпикуляка [3], Т. О. Осташко [4], Д. Норта [5], Е. Фуруботна, Р.Ріхтера [6] та інших науковців. Водночас нових глибинних досліджень потребує питання оцінки природи й практичних проявів інституційних дисбалансів розвитку товарних ринків у напрямі їх зовнішньоекономічної інтеграції до глобального економічного простору, обгрунтування системних заходів подолання таких дисбалансів 3 урахуванням світового досвіду та українських реалій.

Формулювання цілей дослідження. Мета 
статті - розробка комплексу заходів щодо подолання інституційних дисбалансів зовнішньоекономічної інтеграції вітчизняного ринку борошномельнокруп'яної продукції - окреслила низку завдань:

1) встановлення природи та практичних проявів інституційних дисбалансів зовнішньоекономічної інтеграції досліджуваного ринку;

2) обгрунтування комплексу заходів щодо подолання інституційних дисбалансів та очікуваних напрямів їх трансформаційного впливу на розвиток українського ринку БКП;

3) оцінка ефективності переорієнтації вітчизняного агроекспорту з зерна на продукти його переробки на базі відтворювального методичного підходу.

Виклад основних результатів та їх обгрунтування. Авторське визначення категорії «інституиійний дисбаланс»є таким: порушення оптимальних співвідношень між внутрішньою й зовнішньою компонентами державної агропродовольчої політики, неврівноваженість дії формальних інститутів та інституцій, наслідком чого постає незбалансованість кількісно-вартісних пропорцій процесу відтворення як у цілому, так і окремих його складових. У даному дослідженні йдеться про незбалансованість експортно-імпортних товаропотоків сировини й продуктів іiі переробки.

Динаміка зовнішньоторговельних операцій України $є$ наочним свідченням сировинної орієнтації агроекспорту: у міру збільшення ступеня переробки продукції обсяги іiі експорту зменшуються від 6,5 млрд. дол. для зерна до 0,18 i 0,14 млрд. дол. (2017 р.) для борошномельно-круп'яної й хлібобулочної продукції відповідно; таке ж співвідношення притаманне й для сальдо, значення якого зменшується від 6,3 млрд. дол. для зернових культур до 0,15 млрд. дол. для БКП і 0,99 млрд. дол. для хлібопродуктів [7]. Однією з причин існуючих незбалансованих співвідношень $€$ формування сприятливого інституційного середовища для експорту зернових культур і низький рівень модернізації інститутів сприяння експорту продуктів зернопереробки 3 вищою доданою вартістю. Тобто мають місце значні інституційні дисбаланси, що гальмують відтворювальний розвиток вітчизняного ринку БКП.

В Україні потужності із виробництва борошномельної продукції оцінюються на рівні 10 млн. тонн, тобто у 2017 р. коефіцієнт використання наявних потужностей склав всього $19 \%$. Смність вітчизняного борошняного ринку у звітному періоді досягла 1520 тис. т, зменшившись порівняно 32008 р. на $45,3 \%$ за рахунок скорочення обсягів виробництва на $36,1 \%$ та зростання експорту в 1,7 рази (таблиця 1 ). Незважаючи на повільно зростаючий тренд експортних продаж українського борошна за 2011-2017 рр., що $є$ позитивною тенденцією, у 2016 р. різко збільшилися обсяги імпорту продукції ( 3 1,7 тис. т до 41,9 тис. т), що обумовило зростання показника ступеня відкритості ринку (далі - СВР) з 0,09 \% в 2015 р. до $2,39 \%$ в 2016 р. Зростання імпорту відбулося за рахунок товарної групи УКТНЗЕД 1102 «Борошно із зерна інших зернових культур, окрім пшениці», зокрема житнього борошна, що $є$ наслідком структурних трансформацій у товарній структурі зернового виробництва та незбалансованості внутрішньої й зовнішньої складових державної агропродовольчої політики, тобто дії інституційних дисбалансів.

Смність і ступінь відкритості українського ринку борошномельної й круп'яної продукції, тис. тонн"

\begin{tabular}{|c|c|c|c|c|c|c|c|c|c|c|}
\hline \multirow{2}{*}{ Показники } & \multicolumn{9}{|c|}{ Роки } & \multirow{2}{*}{$\begin{array}{c}2017 \text { p. y } \\
\% \text { до } \\
2008 \text { p. }\end{array}$} \\
\hline & 2008 & 2010 & 2011 & 2012 & 2013 & 2014 & 2015 & 2016 & 2017 & \\
\hline \multicolumn{11}{|c|}{ Борошно (коди УКТНЗЕД 1101, 1102) } \\
\hline 1.Виробництво & 3030 & 2632 & 2596 & 2605 & 2565 & 2358 & 2211 & 2085 & 1937 & 63,9 \\
\hline 2. Імпорт & 12,4 & 6,8 & 7,4 & 11,9 & 3,3 & 2,6 & 1,7 & 41,9 & 28,0 & 226,6 \\
\hline 3. Експорт & 264,5 & 91,3 & 124,2 & 161,6 & 221,3 & 253,3 & 306,8 & 371,2 & 444,8 & 168,2 \\
\hline $\begin{array}{l}\text { у\% до виробниц- } \\
\text { тва }\end{array}$ & 8,7 & 3,5 & 4,8 & 6,2 & 8,6 & 10,7 & 13,9 & 17,8 & 23,0 & $\mathrm{X}$ \\
\hline $\begin{array}{l}\text { 4. Смність ринку } \\
(1+2-3)\end{array}$ & 2778 & 2548 & 2479 & 2455 & 2347 & 2107 & 1906 & 1756 & 1520 & 54,7 \\
\hline 5. $C B P, \%(2 / 4)$ & 0,44 & 0,27 & 0,30 & 0,48 & 0,14 & 0,12 & 0,09 & 2,39 & 1,84 & $\mathrm{X}$ \\
\hline \multicolumn{11}{|c|}{ Крупи (коди УКТНЗЕД 1103, 1104) } \\
\hline 1.Виробництво & 363 & 340 & 356 & 364 & 367 & 350 & 358 & 373 & 329 & 90,5 \\
\hline 2. Імпорт & 17,0 & 9,4 & 16,8 & 14,9 & 16,4 & 28,0 & 9,6 & 8,8 & 22,9 & 134,6 \\
\hline 3. Експорт & 75,4 & 74,2 & 85,9 & 75,9 & 95,0 & 92,2 & 50,7 & 56,8 & 74,0 & 98,1 \\
\hline $\begin{array}{l}\text { y\% до виробниц- } \\
\text { тва }\end{array}$ & 20,8 & 21,8 & 24,1 & 20,8 & 25,9 & 26,3 & 14,2 & 15,2 & 22,5 & $X$ \\
\hline $\begin{array}{l}\text { 4. Смність ринку } \\
(1+2-3)\end{array}$ & 304,6 & 275,2 & 286,9 & 303,0 & 288,4 & 285,8 & 316,9 & 325,0 & 277,4 & 91,1 \\
\hline 5. $C B P, \%(2 / 4)$ & 7,87 & 1,14 & 5,85 & 4,91 & 5,69 & 9,78 & 3,02 & 2,71 & 8,26 & $X$ \\
\hline
\end{tabular}

"Розраховано за даними Державної служби статистики України [7] 
Смність вітчизняного круп'яного ринку склала у 2017 р. 277,4 тис. т, зменшившись порівняно 3 2008 р. на 8,9 \% за рахунок скорочення виробництва круп на 9,5\% за одночасного зростання імпорту на $34,6 \%$. У 2017 р. істотно зросли обсяги імпорту круп'яної продукції (у 2,6 рази порівняно з попереднім періодом), обумовивши майже потрійне зростання СВР ринку: з 2,71 \% у 2016 р. до 8,28 \% у 2017 р. (див. табл. 1).

У 2017 р. основними покупцями українських круп були Білорусь (19,64 \%), Польща $(14,7 \%)$, Німеччина (12,3\%), пшеничного борошна - Китай $(24,1 \%)$, Ангола $(10,8 \%)$, Молдова $(8,2 \%)$, борошна із зерна інших культур - Хорватія $(35,4 \%)$, Польща $(17,3 \%)$, Молдова (11,2 \%). Водночас імпортні товаропотоки борошна із зерна інших культур, окрім пшениці, надходили в Україну із Білорусі $(98,7 \%)$ [7].

Український ринок борошномельнокруп'яної продукції має потужний виробничий і експортний потенціал, реалізація яких покликана забезпечити ефективність його функціонування. Інтеграція даного ринку до глобального економічного простору стримується невирішеністю низки інституційних дисбалансів зовнішньоекономічної інтеграції, до яких можна віднести наступні:
1) одностороння орієнтація державної агропродовольчої політики на експорт сировинних товарів (зокрема, зерна), інституційна й фінансова підтримка даного напряму;

2) практично повна відсутність механізмів державної підтримки експорту борошномельнокруп'яної продукції;

3) високі технічні бар'єри експорту вітчизняної БКП на ринки країн ЄС та інші ринки;

4) відсутність серед функцій державних інституцій чітко визначених заходів сприяння розвитку експорту продовольчих товарів, функцій моніторингу їх впливу на структурно-динамічні зміни агропродовольчого експорту та контролю виконання таких заходів;

5) домінуюча сировинна експортна орієнтація ПАТ «Державна продовольчо-зернова корпорація України» (далі - ДПЗКУ);

6) пасивність профільних інституцій, слабкість їх впливу на розвиток експорту БКП.

Комплекс заходів щодо подолання інституційних дисбалансів зовнішньоекономічної інтеграції вітчизняного ринку БКП, розроблений автором, узагальнено в таблиці 2. Розглянемо їх більш детально.

Комплекс заходів подолання інституційних дисбалансів зовнішньоекономічної інтеграції вітчизняного ринку борошномельно-круп'яної продукції

\begin{tabular}{|c|c|c|}
\hline $\begin{array}{c}\text { Інституційні } \\
\text { дисбаланси }\end{array}$ & Пропозиції & Очікуваний результат \\
\hline $\begin{array}{l}\text { 1. Одностороння орієн- } \\
\text { тація державної агроп- } \\
\text { родовольчої політики } \\
\text { на експорт сировинних } \\
\text { товарів (зокрема, зер- } \\
\text { на), інституційна й фі- } \\
\text { нансова підтримка да- } \\
\text { ного напряму }\end{array}$ & $\begin{array}{l}\text { На один рік припинити дію механізму } \\
\text { бюджетного відшкодування ПДВ при експорті зерно- } \\
\text { вих культур, внести зміни до пП. 195.1.1. Податкового } \\
\text { кодексу України, вилучивши з переліку товарів, опе- } \\
\text { рації з вивезення яких оподатковуються за нульовою } \\
\text { ставкою ПДВ, позиції УКТЗЕД 1001-1008 [8]. } \\
\text { Щоквартальний моніторинг даного заходу на параме- } \\
\text { три розвитку ринків зерна і БКП. }\end{array}$ & $\begin{array}{l}\text { Переорієнтація фінансо- } \\
\text { вих потоків з підтримки } \\
\text { експорту зерна на підт- } \\
\text { римку експорту БКП; } \\
\text { зростання виробництва й } \\
\text { експорту БКП, кількості } \\
\text { зайнятих, податків і соц- } \\
\text { внесків. }\end{array}$ \\
\hline $\begin{array}{l}\text { 2. Практично повна } \\
\text { відсутність механізмів } \\
\text { державної підтримки } \\
\text { експорту БКП; } \\
\text { високі технічні бар'єри } \\
\text { експорту вітчизняної } \\
\text { борошномельної й } \\
\text { круп'яної продукції на } \\
\text { ринки країн ЄС та інші } \\
\text { ринки }\end{array}$ & $\begin{array}{l}\text { 1. Розробити та впровадити державну підтримку у фо- } \\
\text { рмі } 50 \text { \%-ї компенсації вартості сертифікації продук- } \\
\text { uії вітчизняних борошномельних підприємств за між- } \\
\text { народними нормами й стандартами } \\
\text { 2. Формування якісної сировинної бази для розвитку } \\
\text { експорту вітчизняної БКП, співпраця переробних під- } \\
\text { приємств із зерновими обслуговуючими кооператива- } \\
\text { ми } \\
\text { 3. Впровадження ринкових експортних стратегій, мі- } \\
\text { німізація цінових конкурентних переваг продукції на } \\
\text { глобальному ринку } \\
\text { 4. Розробка за участю державних і профільних інсти- } \\
\text { туцій національної програми збагачення борошна мік- } \\
\text { ронутрієнтами }\end{array}$ & $\begin{array}{l}\text { Зменшення витрат пере- } \\
\text { робних підприємств на } \\
\text { сертифікацію продукції; } \\
\text { зростання ії якісних па- } \\
\text { раметрів та вітамінізація } \\
\text { відповідно до міжнарод- } \\
\text { них вимог; розвиток } \\
\text { ефективних форм взає- } \\
\text { модії переробних підп- } \\
\text { риємств із зерновими } \\
\text { обслуговуючими коопе- } \\
\text { ративами, зокрема, бага- } \\
\text { тофункціональними }\end{array}$ \\
\hline $\begin{array}{l}\text { 3. Відсутність серед } \\
\text { функцій державних } \\
\text { інституцій чітко визна- } \\
\text { чених заходів підтрим- } \\
\text { ки продовольчого екс- } \\
\text { порту }\end{array}$ & $\begin{array}{l}\text { Розширити функції відділу стратегії розвитку ринків } \\
\text { харчових продуктів Департаменту продовольства Мі- } \\
\text { ністерства аграрної політики та продовольства Украї- } \\
\text { ни за рахунок конкретизації заходів сприяння розвитку } \\
\text { експорту продтоварів, функцї̈ моніторингу їх впливу } \\
\text { на зміни агропродовольчого експорту, функиї спів- } \\
\text { праці з іншими державними й профільними інституці- } \\
\text { ями у сфері розвитку продовольчого експорту }\end{array}$ & $\begin{array}{l}\text { Позитивні зміни у струк- } \\
\text { турі й динаміці експорту } \\
\text { продуктів переробки, у } \\
\text { т.ч. БКП і хлібопродук- } \\
\text { тів, коригування заходів } \\
\text { впливу за результатами } \\
\text { моніторингу, їх резуль- } \\
\text { тативність }\end{array}$ \\
\hline
\end{tabular}


Продовження табл.2

\begin{tabular}{|c|c|c|}
\hline $\begin{array}{c}\text { Інституційні } \\
\text { дисбаланси }\end{array}$ & Пропозиції & Очікуваний результат \\
\hline $\begin{array}{l}\text { 4. Домінуюча сировин- } \\
\text { на експортна орієнтація } \\
\text { ПАТ «ДПЗКУ» }\end{array}$ & $\begin{array}{l}\text { Закріпити за ПАТ «ДПЗКУ» статус провідного підпри- } \\
\text { ємства для ведення переговорів щодо постачання укра- } \\
\text { їнської зернопереробної продукції на зовнішні ринки; } \\
\text { відкриття представництв в країнах-імпортерах БКП }\end{array}$ & $\begin{array}{lr}\text { Розробка } & \text { ефективних } \\
\text { експортних } & \text { ринкових } \\
\text { стратегій } & \end{array}$ \\
\hline $\begin{array}{l}\text { 5. Пасивність профіль- } \\
\text { них інституцій, слаб- } \\
\text { кість їх впливу на роз- } \\
\text { виток експорту БКП }\end{array}$ & $\begin{array}{l}\text { Активізація діяльності ГС «Борошномели України», iї } \\
\text { тісна співпраця з державними інституціями, участь у } \\
\text { розробці національної програми збагачення борошна } \\
\text { мікронутрієнтами }\end{array}$ & $\begin{array}{l}\text { Консолідація зусиль } \\
\text { держави й проф. спілки } \\
\text { для спільного вирішення } \\
\text { проблем }\end{array}$ \\
\hline
\end{tabular}

*Розроблено автором з використанням джерел $[1,8,9]$

Впровадження системи поетапних заходів для успішного розвитку експорту БКП передбачає залучення відповідного фінансового забезпечення. У даному напрямі доцільно переорієнтувати бюджетні фінансові потоки 3 підтримки експорту зерна на стимулювання експорту продуктів його переробки. Пропонуємо на один рік припинити дію механізму бюджетного відшкодування ПДВ при експорті зернових культур, внести зміни до пП. 195.1.1. Податкового кодексу України [8], вилучивши з переліку товарів, операції з вивезення яких оподатковуються за нульовою ставкою ПДВ, позиції УКТЗЕД 1001-1008 (зернові культури). Одночасно запровадити щоквартальний моніторинг впливу даного заходу на параметри розвитку суміжних ринків зерна і БКП, зокрема, рівень внутрішніх і експортних цін, обсяги експортноімпортних товаропотоків у вартісному й натуральному вимірі, зміни у структурі агропродовольчого експорту тощо. Результати такого моніторингу сформують аналітичну базу для обгрунтування доцільності продовження дії даного інституційного заходу або його скасування в наступному періоді.

Інституційна проблема високих технічних бар'єрів експорту української БКП на зовнішні ринки $є$ багаторівневою, відтак, вимагає впровадження низки взаємопов'язаних заходів та спільних зусиль як держави, так i безпосередніх виробників (див. табл. 2). Враховуючи регуляторну практику світових експортерів борошна, пропонуємо реалізувати державну підтримку у формі 50\%-ї компенсації вартості сертифікації продукції вітчизняних борошномельних підприємств за міжнародними стандартами.

Одночасно з метою виконання вимог зовнішніх покупців щодо якості та безпечності української БКП переробні підприємства за підтримки держави повинні поетапно вирішувати завдання формування якісної сировинної бази. Одним із інструментів його вирішення $\epsilon$ контрактація переробників і зернових обслуговуючих кооперативів, що дозволить забезпечити власне виробництво сировиною із заданими параметрами якості (зокрема, пшеницею твердих сортів, 2 класу, житом тощо). Іншим напрямом $є$ участь переробних підприємств на правах асоційованих членів у діяльності зернових обслуговуючих кооперативів (див. табл. 2). Така суб'єктна інтеграція, з одного боку, забезпечить для кооперативів гарантований ринок збуту їх продукції, з іншого, дозволить переробникам сформувати необхідну за обсягами та якістю сиро- винну базу для виробництва БКП.

У перспективі головною складовою конкурентної стратегії вітчизняних експортерів БКП на глобальному ринку повинна стати не цінова конкуренція (нині головною конкурентною перевагою українського борошна є низька ціна), а впровадження ринкових стратегій, які передбачають забезпечення диверсифікації і розширення ринків збуту, постачань сировини й товарів для національної економіки [2, с. 5]. Слід відзначити перші успішні кроки в диверсифікації експорту українського борошна, що дозволило вітчизняним експортерам закріпити свої позиції на ринках Азії (33\% експорту в 2016 р.), Близького Сходу (23\%) та Африки (16\%) [9]. Водночас необхідно реалізовувати іншу складову ринкових стратегій, пов'язану з формуванням нових товарних і географічних ринків продукції власного виробництва. Сьогодні в країнах Азії формуються нові продовольчі ринки і нова культура споживання, відтак, українські виробники здатні зайняти в них сегмент високоякісної продукції з помірними цінами й стати альтернативою західним товарам [2, с. 5].

У напрямі становлення нових ринків унікальних товарів українським виробникам БКП доцільно розширити товарний асортимент, організувати випуск інноваційних видів продукції (наприклад, борошняних композиційних сумішей), розвивати органічний та вітамінізований напрями виробництва. При цьому асортимент продукції, а також способи її фасування, упаковки й маркування необхідно адаптувати до вимог країни-імпортера. У більшості держав - імпортерів борошномельної продукції діють вимоги щодо ii збагачення мікронутрієнтами (вітамінами i мікроелементами). Близько в 59 країнах світу діють законодавчі акти, регулюючі обов'язкове збагачення мікронутрієнтами одного або декількох сортів борошна [10]. Враховуючи світовий досвід, доцільно розробити національну програму збагачення борошномельної продукції мікронутрієнтами та механізми іiі реалізації (допомога ЮНІСЕФ, державні інтервенції вітамінізованого борошна тощо), залучивши до цього заходу ГС «Борошномели України» й державні інституції (див. табл. 2). Впровадження даної програми сприятиме інтеграції борошняного ринку України до глобального ринкового простору.

Підвищення ступеню стабілізуючого впливу управлінських рішень органів влади у сфері стимулювання експорту продуктів харчування з високою 
доданою вартістю обумовлює необхідність розширення, конкретизації й узгодження функцій державних інституцій (див. табл. 2). Так, для відділу стратегії розвитку ринків харчових продуктів Департаменту продовольства Міністерства аграрної політики та продовольства пропонуємо розширити його функції за рахунок конкретизації заходів сприяння розвитку експорту продовольчих товарів, запровадити функцію оперативного моніторингу їх впливу на структурнодинамічні зміни агропродовольчого експорту [11]. В ході моніторингу доцільно акцентувати увагу на два напрями: (1) цінові співвідношення рівнів експортних, світових і імпортних цін БКП; (2) фізичні обсяги експортно-імпортних товаропотоків, для забезпечення продовольчої безпеки держави. Виконання функції моніторингу передбачає періодичне коригування заходів державного впливу на основі зворотного зв'язку та підвищення їх ефективності.

Експортною стратегією України передбачено утворення Oфicy з просування експорту при Мінекономрозвитку, який на сьогодні має статус консультативно-дорадчого органу, а в майбутньому може перетворитися на повнофункціональну інституцію з підтримки та просування експорту [1]. У зв'язку з цим важливо забезпечити співпрацю Департаменту продовольства Мінагрополітики та продовольства України 3 даною інституцією та узгодити їх функції в напрямі просування продовольчих товарів, у т.ч. БКП, на зовнішні ринки.

Також пропонуємо переорієнтувати діяльність ПАТ «Державна продовольчо-зернова корпорація України» з експорту сировини на продукти зернопереробки (див. табл. 2), закріпити за ним статус провідного підприємства для ведення переговорів щодо постачання української зернопереробної продукції на зовнішні ринки збуту, розширити його завдання та функції (формування і поліпшення іміджу України як провідної держави не тільки на світових аграрних, але й продовольчих ринках). Загальна потужність млинів корпорації дозволяє щорічно виробляти майже 650 тис. т борошномельної продукції [12]. Відтак, маючи значний сировинний, виробничий та логістичний потенціал, ДПЗКУ може виконувати функцію просування експорту вітчизняної зернової продукції на зовнішні ринки. Цьому сприятиме також відкриття торгових представництв ПАТ «ДПЗКУ» у головних

країнах-імпортерах українського борошна, зокрема країнах Азії.

Важливою інституційною складовою розвитку експорту української БКП є активізація діяльності профільної інституції ГС «Борошномели України», розвиток iï співпраці з державними інституціями, участь у розробці національної програми вітамінізації борошна (див. табл. 2). Слід відзначити, що підтримку інституційної спроможності профільних асоціацій розвивати експортні ринки збуту здійснюють Продовольча та сільськогосподарська організація ООН (ФАО) і Свропейський банк реконструкції та розвитку. Так, за програмою співробітництва 3 даними міжнародними інституціями спілка «Борошномели України» та іiі члени у 2016 р. взяли участь у виставках в Гонконзі, Індонезії, ОАЕ та інших країн світу, де українські виробники змогли представити свою продукцію та налагодити торговельні відносини з місцевими учасниками ринку [9]. Дана співпраця позитивно вплинула на динаміку експортних товаропотоків борошна: в 2016 р. експортні поставки борошна 3 України в країни Східної Азії збільшились на $19 \%$.

Ефективність переорієнтації українського експорту з зерна на продукти його переробки, зокрема борошно, можна оцінити за допомогою показника доданої вартості, використовуючи відтворювальний методичний підхід [13]. За даними Державної служби статистики України [7], обсяг експорту пшениці в 2017 р. склав 17314,3 тис. тонн. Для оцінки ефективності структурних змін українського агроекспорту розглянемо три сценарних варіанти:

1) зменшення обсягів пшеничного експорту на $1 \%$ (на 173,1 тис. т), виробництво борошна із даної пшениці в обсязі 133,32 тис. т (вихід - $77 \%$ ) та його наступний експорт;

2) скорочення обсягів зернового експорту на $5 \%$ (на 865,7 тис. т), виробництво та експорт 666,6 тис. т борошномельної продукції;

3) зменшення обсягів пшеничного експорту на $7 \%$ (на 1212 тис. т), виробництво та експорт борошна, виробленого із даної пшениці, в обсязі 933,24 тис. т.

Результати проведених розрахунків із визначення приросту (зменшення) показника доданої вартості в торговому секторі зернового та борошняного ринків, а також виробничому секторі ринку борошномельної продукції, узагальнено в таблиці 3.

Таблиця 3

Приріст доданої вартості у секторах зернового й борошняного ринків внаслідок переорієнтації частини експорту пшениці на експорт борошна*

\begin{tabular}{|l|c|c|c|}
\hline \multicolumn{2}{|c|}{ ПОКАЗНИКИ } & \multicolumn{3}{|c|}{ Сценарні варіанти зменшення експорту } \\
\cline { 2 - 4 } & I - 1\% & \multicolumn{1}{|c|}{ II - 5\% } & III - 7\% \\
\hline \multicolumn{3}{|c|}{ Торговий сектор зернового ринку (зовнішня реалізація) } \\
\hline 1. Обсяги експорту пшениці в 2017 р., тис тонн & 173,1 & \multicolumn{3}{|c|}{17314,3} \\
\hline 2. Зменшення обсягів експорту пшениці, тис. тонн & -53172 & -265861 & -372206 \\
\hline 3. Зменшення доданої вартості, тис. грн. & \\
\hline
\end{tabular}


Продовження табл.3

\begin{tabular}{|c|c|c|c|}
\hline \multirow{2}{*}{ ПОКАЗНИКИ } & \multicolumn{3}{|c|}{$\begin{array}{c}\text { Сценарні варіанти зменшення експорту } \\
\text { пшениці }\end{array}$} \\
\hline & I $-1 \%$ & II $-\mathbf{5 \%}$ & III - 7\% \\
\hline \multicolumn{4}{|c|}{ Виробничий сектор борошняного ринку } \\
\hline 1. Приріст виробництва борошна, тис. т (вихід - 77 \%) & 133,32 & 666,60 & 933,24 \\
\hline 2. Приріст доданої вартості, тис. грн. & 82651,8 & 413259,0 & 578562,6 \\
\hline 3. Приріст заробітної плати (соціальний ефект), тис. грн. & 31656,9 & 158284,3 & 221598,0 \\
\hline \multicolumn{4}{|c|}{ Торговий сектор борошняного ринку (зовнішня реалізація) } \\
\hline 1. Приріст експорту борошномельної продукції, тис. т & 133,32 & 666,60 & 933,24 \\
\hline 2. Приріст доданої вартості, тис. грн. & 35036,5 & 175182,6 & 245255,7 \\
\hline \multicolumn{4}{|c|}{ Відтворювальний ефект реалізації заходу } \\
\hline Загальний приріст доданої вартості, тис. грн. & 64516,1 & 322580,6 & $451612,8 X$ \\
\hline
\end{tabular}

*Розраховано автором за даними Державної служби статистики України [7].

Згідно розрахункам, зменшення обсягів експорту пшениці всього на $1 \%$, виробництво із даної пшениці 133,32 тис. т борошна (36 \% від обсягів його експорту в 2017 р.) та його зовнішня реалізація дозволить отримати загальний приріст доданої вартості у секторах ринків на суму 64,52 млн. грн., у т.ч. майже 50 \% (31,66 млн. грн.) за рахунок соціальної складової - заробітної плати зайнятих у виробничому секторі борошняного ринку. Скорочення зернового експорту на 5 \% згенерує загальний приріст доданої вартості на суму 322,58 млн. грн.; приріст доданої вартості за $7 \%$-го зменшення пшеничного експорту складе 451,62 млн. грн. (див. табл. 3). Таким чином, включення у національний ланцюг створення доданої вартості виробничого сектору ринку борошномельної продукції, який $\epsilon$ ресурсоутворювальним сектором («точкою зростання») у ринковій системі, дозволяє отримати значний соціальний, відтворювальний та податковий ефекти (таблиця 4) навіть за 1 \%-го скорочення обсягів сировинного експорту.

За розрахунками, загальний приріст податкових надходжень від суб' єктів зернового та борошняного ринків у результаті $1 \%$-го зменшення обсягів експорту пшениці складає 21,98 млн. грн (І сценарний варіант). Скорочення зернового експорту на $5 \%$ згенерує приріст податкових надходжень на 109,89 млн. грн. (II сценарний варіант); приріст податків за $7 \%$-го зменшення пшеничного експорту досягне 153,86 млн. грн. (III сценарний варіант). У структурі приросту податкових надходжень 65,4 \% припадає на бюджетне відшкодування експортного ПДВ (отриману державою економію за даним напрямом витрат), 31,7\% - на приріст соціального внесків, 2,9\% - податок на прибуток (див. табл. 4).

Таблиця 4

Приріст податкових надходжень від суб'сктів зернового та борошняного ринків внаслідок переоріснтації частини експорту пшениці на експорт борошна, тис. грн."

\begin{tabular}{|c|c|c|c|}
\hline \multirow{2}{*}{ Платежі до бюджету } & \multicolumn{3}{|c|}{$\begin{array}{l}\text { Сценарні варіанти зменшення експорту } \\
\text { пшениці } \\
\end{array}$} \\
\hline & $\mathrm{I}-\mathbf{1 \%}$ & II $-\mathbf{5 \%}$ & III - 7\% \\
\hline \multicolumn{4}{|c|}{ Торговий сектор зернового ринку (зовнішня реалізація) } \\
\hline $\begin{array}{l}\text { 1. Економія від бюджетного невідшкодування експортного } \\
\text { ПДВ трейдерам }\end{array}$ & 130605,2 & 653026,1 & 914236,6 \\
\hline 2. Податок на прибуток (18 \%) & $-9571,3$ & $-47856,7$ & $-66999,4$ \\
\hline Усього: & 121033,9 & 605169,4 & 847237,2 \\
\hline \multicolumn{4}{|c|}{ Виробничий сектор борошняного ринку } \\
\hline 1. Соціальний внесок & 6964,6 & 34823,2 & 48752,5 \\
\hline 2. Податок на прибуток (18\%) & 3910,3 & 19551,4 & 27372,0 \\
\hline Усього: & 10874,92 & 54374,61 & 76124,45 \\
\hline \multicolumn{4}{|c|}{ Торговий сектор борошняного ринку (зовнішня реалізація) } \\
\hline 1. Бюджетне відшкодування експортного ПДВ & $-116235,1$ & $-581175,7$ & $-813646,0$ \\
\hline 2. Податок на прибуток (18 \%) & 6306,0 & 31530,2 & 44142,3 \\
\hline Усього: & $-109929,1$ & $-549645,5$ & $-769503,7$ \\
\hline
\end{tabular}


Продовження табл.4

\begin{tabular}{|l|c|c|c|}
\hline \multirow{2}{*}{ Платежі до бюджету } & \multicolumn{3}{|c|}{ Сценарні варіанти зменшення експорту } \\
& пшениці \\
\cline { 2 - 4 } & $\mathbf{I - 1 \%}$ & II - 5\% & III - 7\% \\
\hline \multicolumn{3}{|c|}{ Податковий ефект реалізації заходу } \\
\hline 1. Соціальний внесок & 6964,6 & 34823,2 & 48752,5 \\
\hline 2. Бюджетне відшкодування експортного ПДВ & 14370,1 & 71850,4 & 100590,6 \\
\hline 3. Податок на прибуток (18\%) & 645,0 & 3224,9 & 4514,8 \\
\hline Усього: & $\mathbf{2 1 9 7 9 , 7}$ & $\mathbf{1 0 9 8 9 8 , 5}$ & $\mathbf{1 5 3 8 5 8 , 0}$ \\
\hline
\end{tabular}

*Розраховано за даними табл. 3.

Наведені в табл. 4 розрахунки наочно ілюструють перерозподіл бюджетних коштів у випадку переорієнтації частини експорту пшениці на експорт борошна. Так, за умови зовнішньої реалізації 173,1 тис. т пшениці сума бюджетного відшкодування ПДВ складе близько 130,6 млн. грн., а за умови експорту 133,32 тис. т борошна, виробленої з цієї пшениці, сума відшкодування ПДВ буде зменшена на 14,4 млн. грн. Загалом у 2017 р. за умови $100 \%$-го відшкодування експортного ПДВ його обсяг для експортерів пшениці склав близько 13,06 млрд. грн., а для експортерів борошна - всього 0,32 млрд. грн. Відтак, за умови припинення дії механізму бюджетного відшкодування ПДВ при експорті зернових культур сума річної економії виплат склала б 13,06 млрд. грн. (і це тільки за УКТЗЕД 1001 «шениця і меслин»); іiі обсягу вистачило б на впровадження усіх запропонованих заходів щодо стимулювання експорту вітчизняних продуктів зернопереробки (див. табл. 2).

Експортною стратегією України передбачено розроблення секторальної стратегії щодо харчової та переробної промисловості на основі проведеного аналізу тенденцій до розвитку світової економіки [1]. Головними компонентами секторальної стратегії повинні стати ринкові, виробничі, технологічні, однак не цінові стратегії, які є найменш перспективними на глобальному ринку. На думку В.В. Ліпова (і ми підтримуємо цю позицію), державна політика просування експорту «вимагає тонкого калібрування підтримки підприємств, які за рахунок використання нових технологій, кращої організації виробничого процесу, диференціації ринків збуту спроможні обмежити вплив цінових чинників на конкуренту позицію на зовнішніх ринках і певним чином дестимулювати виробників, які задовольняються тільки ціновими перевагами» [3, с. 7]. Відтак, ефективна державна політика стимулювання експорту продовольчих товарів, у т.ч. БКП, повинна бути гнучкою та диференційованою, орієнтованою на підтримку інноваційних виробництв та підприємств, у т.ч. малих і середніх, готових до впровадження конкурентних експортних стратегій.

Висновки та перспективи подальших досліджень. У ході дослідження визначено природу інституційних дисбалансів та їх практичні прояви у сфері зовнішньоекономічної інтеграції вітчизняного ринку БКП. Показано, що наслідком трансформаційного впливу інституційних дисбалансів $є$ втрати доданої вартості переробних підприємств і податкових надходжень держави у національному ланцюгу вартості. До головних інституційних дисбалансів, що гальмують експорт борошномельно-круп'яної продукції, віднесено, зокрема, інституційну й фінансову підтримку експорту зернових культур, практично повну відсутність механізмів державної підтримки експорту зернопродуктів, обмеженість функцій державних і профільних інституцій у сфері моніторингу й сприяння розвитку експорту продуктів переробки з високою доданою вартістю.

За результатами дослідження розроблено комплекс взаємопов'язаних заходів щодо подолання існуючих дисбалансів шляхом інституційного оформлення переорієнтації бюджетних коштів 3 підтримки експорту зерна на експорт БКП, компенсації частини вартості міжнародної сертифікації продукції підприємствекспортерів, стимулювання їх до впровадження ринкових експортних стратегій, формування якісної сировинної бази шляхом розвитку контрактної й суб'єктної інтеграції переробних підприємств і зернових обслуговуючих кооперативів, розширення функцій й тісної співпраці державних і профільних інституцій вітчизняного ринку. 3 використанням відтворювального методичного підходу здійснено оцінку ефективності переорієнтації експортних товаропотоків зерна й борошна. Проведені розрахунки довели, що зменшення обсягів експорту пшениці всього на $1 \%$ за одночасного виробництва із даної пшениці 133,32 тис. т борошна та його експорту дозволить отримати загальний приріст доданої вартості, заробітної плати і податкових надходжень у секторах зернового й борошняного ринків на суму 64,52, 31,66 і 21,98 млн. грн. відповідно.

Наукова новизна проведеного дослідження полягає в обгрунтуванні природи інтеграційних дисбалансів та сучасних форм їх прояву у сфері зовнішньоекономічної інтеграції українського ринку борошномельнокруп'яної продукції. Теоретичне значення результатів дослідження полягає в розвитку концептуальних положень зовнішньої ринкової інтеграції в інституційному вимірі, практичне значення визначається можливістю використання авторських розробок державними й профільними інституціями в ході формування зовнішньоекономічної стратегії розвитку вітчизняного ринку БКП. Перспективи подальших досліджень полягають в обгрунтуванні інституційних дисбалансів розвитку стратегічних агропродовольчих ринків України та системних заходів їх подолання в умовах активізації зовнішньої інтеграції. 


\title{
Література
}

1. Експортна стратегія («дорожня карта» стратегічного розвитку торгівлі) України на 2017-2021 роки. Затверджено Розпорядженням Кабінету Міністрів України № 1017-p від 27 грудня 2017 p. URL: http://zakon2.rada.gov.ua/laws/show/1017-2017-\%D1\%80 (дата звернення 25.10.2018).

2. Липов В.В. Конкурентная стратегия Украины в условиях глобализации. Экономика Украины. 2018. №4. C. 3-17.

3. Малік М. Й., Шпикуляк О. Г. Інститути та інституції у розвитку аграрної сфери економіки. Економіка АПК. 2011. №7. С. 169-176.

4. Осташко Т. О. Можливості та обмеження експорту сільськогосподарських товарів у зоні тарифних квот ЄС. Стратегічні пріоритети. 2016. №1 (38). С. 99-105.

5. North D. Institutions, Institutional Change and Economic Performance. Cambridge: Cambridge University Press, 1990. $620 \mathrm{p}$.

6. Furubotn E. G., Richter R. Institutions and Economic Theory: The Contribution of the New Institutional Economics. URL: https://www.press.umich.edu/6715/institutions_and economic theory (application date October 26, 2018).

7. Офіційний сайт Державної служби статистики України. Зовнішньоекономічна діяльність. URL: http://www.ukrstat.gov.ua (дата звернення 25.10.2018).

8. Податковий кодекс України від 01.10 .2013 p. № 2755-XVII $\quad$ URL: http://zakon2.rada.gov.ua/laws/show/2755-17 (дата звернення 26.10.2018).

9. Ринок зерна України: від експорту сировини до готової продукції. URL: https://agronews.ua/node/82481 (дата звернення 26.10.2018).

10. Ткаченко С. Обогащение муки микронутриентами на мельнице. Хранение и переработка зерна. 2010. № 4(130). С.15-17.

11. Положення про Департамент продовольства Міністерства аграрної політики та продовольства України: затверджено Наказом Міністерства аграрної політики та продовольства України № 310 від 03.08.2015 p. URL: http://minagro.gov.ua/ministry?nid=3010 (дата звернення 25.10.2018).

12. Офіційний сайт ПАТ «Державна продовольчо-зернова корпорація України». URL: http://www.pzcu.gov.ua/ua/about (дата звернення 25.10.2018).

13. Nikishyna O. V. Methodical approach to the evaluation the efficiency of integrated commodity market: scientific report. Saarbrucken, Germany: LAMBERT Academic Publishing, 2017. 89 p.

\section{Никишина О.В.}

доктор экономических наук, старший научный сотрудник

E-mail: ksenkych@gmail.com

Муратов О.M.

кандидат экономических наук, соискатель

отдел рыночных механизмов и структур

Институт проблем рынка и экономико-экологических исследований НАН Украины

Французский бульвар, 29, г.Одесса, Украина, 65044

E-mail:omuratov45@gmail.com

\section{МЕРЫ ПРЕОДОЛЕНИЯ ИНСТИТУЦИОНАЛЬНЫХ ДИСБАЛАНСОВ ВНЕШНЕЭКОНОМИЧЕСКОЙ ИНТЕГРАЦИИ УКРАИНСКОГО РЫНКА МУКОМОЛЬНО-КРУПЯНОЙ ПРОДУКЦИИ}

\begin{abstract}
Эфффективное функционирование украинского рынка мукомольно-крупяной продукции предусматривает реализацию его мощного экспортного потенциала, что соответствует положениям Экспортной стратегии Украины на 2017-2021 годы. Внешнеэкономическую интеграцию отечественного рынка сдерживает ряд институциональных дисбалансов. Анализ их сущности, видов, направлений и мер преодоления формирует актуальную задачу для новых исследований в данном научно-прикладном направлении.
\end{abstract}

Целью статьи является разработка комплекса мер по преодолению институциональных дисбалансов внешнеэкономической интеграции украинского рынка муки и круп. Для достижения цели в статье 
решены следующие задачи: (1) определены сущность и виды институциональных дисбалансов внешнеэкономической интеграции рынка; (2) обоснован комплекс мер их преодоления; (3) на основе воспроизводственного методического подхода оценена эффективность переориентации аграрного экспорта из зерна на продукты его переработки.

Сущность институциональных дисбалансов заключается в нарушении оптимального соотношения между внутренней и внешней компонентами государственной агропродовольственной политики. На практике это приводит к финансовой и институциональной поддержке направления зернового экспорта, отсутствию механизмов государственной поддержки экспорта зерновых продуктов с высокой добавленной стоимостью, ограниченности функций государственных и профильных институтов рынка. В ходе исследования разработан комплекс мер преодоления институциональных дисбалансов внешней интеграции украинского рынка мукомольно-крупяной продукции, в частности: (1) модернизация институтов поддержки экспорта продуктов переработки; (2) стимулирование предприятий-экспортеров к внедрению рыночных экспортных стратегий, развитие их интеграционных взаимодействий с зерновыми обслуживающими кооперативами; (3) расширение функций и тесное сотрудничество государственных и профильных институтов рынка.

Согласно расчетам, переориентация 1 \% экспорта пшеницы на экспорт муки позволит получить прирост добавленной стоимости и налоговых поступлений на сумму 64,52 и 21,98 млн. грн., что доказывает эффективность наращивания экспорта мукомольной продукции. Теоретическое значение исследования заключается в развитии концептуальных положений внешней рыночной интеграции в институциональном измерении, практическое - в использовании авторских разработок государственными и профильными институтами в ходе формирования внешнеэкономической стратегии развития рынка мукомольно-крупяной продукции.

Ключевые слова: институциональный дисбаланс, рынок, внешнеэкономическая интеграция, экспорт, добавленная стоимость, меры государства, цепочка стоимости.

\author{
Nikishina 0. \\ Doctor of Economics, Senior Researcher \\ E-mail: ksenkych@gmail.com \\ Muratov 0.
}

Candidate of Economics, applicant

Department of Market Mechanisms and Structures

Institute of Market Problems and Economic \& Ecological Research

of National Academy of Sciences of Ukraine

Frantsuzskiy boulevard, 29, Odesa, Ukraine, 65044

E-mail:omuratov45@gmail.com

\title{
MEASURES TO OVERCOME INSTITUTIONAL IMBALANCES OF FOREIGN ECONOMIC INTEGRATION OF UKRAINIAN MARKET OF FLOUR-GRINDING AND CEREAL PRODUCTS
}

\begin{abstract}
Effective functioning of Ukrainian market of flour-grinding and cereal products envisages for the realization of its powerful export potential, which corresponds to the provisions of Export Strategy of Ukraine for 2017-2021 years. Foreign economic integration of the domestic market is hampered by a number of institutional imbalances. The analysis of their essence, types, directions and measures of overcoming forms an urgent task for new researches in this scientific and applied direction.

The aim of the article is to develop a set of measures to overcome the institutional imbalances of foreign economic integration of Ukrainian market of flour-grinding and cereal products. To achieve the aim the following tasks have been solved in the article: (1) the essence and types of institutional imbalances of foreign economic integration of the market have been determined; (2) a set of measures to overcome them has been substantiated; (3) on the basis of the reproduction methodical approach, the efficiency of the reorientation of the agrarian export from grain to the products of its processing has been estimated.

The essence of institutional imbalances is the violation of the optimal balance between the internal and external components of the state agro-food policy. In practice, this leads to financial and institutional support for the direction of grain exports, the lack of mechanisms for state support for the export of grain products with high added value, the limited functions of state and specialized institutions of the market. In the course of the study, a complex of measures to overcome the institutional imbalances of foreign integration of the Ukrainian market of flour-grinding and cereal products has been developed, in particular: (1) modernization of the institutions supporting the export of processed products; (2) encouraging of export-
\end{abstract}


ing companies to implement market export strategies, developing of their integration with grain service cooperatives; (3) expansion of functions and close cooperation of state and profile institutions of the market.

According to the calculations, the reorientation of $1 \%$ of wheat exports to flour exports will allow to get an increase in value added and tax revenues of 64,52 and 21,98 million hryvnas, which proves the effectiveness of increasing the export of flour mill products. The theoretical significance of the research is the development of the conceptual provisions of foreign market integration in the institutional dimension, and the practical one - in using author's developments by state and profile institutions in the course of forming of the foreign economic strategy for the development of the market for flour-grinding and cereal products.

Keywords: institutional imbalance, market, foreign economic integration, export, value added, state measures, value chain.

\section{References}

1. Eksportna strategiâ («dorožnâ karta» strategičnogo rozvitku torgìvlì) Ukraïni na 2017-2021 roki. Zatverdženo Rozporâdžennâm Kabìnetu Mìnìstrìv Ukraïni № 1017-r vìd 27 grudnâ 2017 r. (2017). Retrieved October 25, 2018, from http://zakon2.rada.gov.ua/laws/show/1017-2017-\%D1\%80

2. Lipov, V. V. (2018). Konkurentnaâ strategiâ Ukrainy v usloviâh globalizacii. Èkonomika Ukrainy, (4), 3-17.

3. Malik, M. Y., \& Shpykuliak, O. H. (2011). İnstituti ta ìnstituciï rozvitku agrarnoï sferi ekonomìki.

Ekonomika APK, (7), 169-176.

4. Ostashko, T. O. (2016). Možlivostì ta obmežennâ eksportu sil's's'kogospodars'kih tovarìv u zonì tarifnih kvot ÊS. Strategični Prioriteti, (1 (38)), 99-105.

5. North, D. (1990). Institutions, Institutional Change and Economic Performance. Cambridge: Cambridge University Press.

6. Furubotn, E. G., \& Richter, R. Institutions and Economic Theory: The Contribution of the New Institutional Economics. Retrieved October 26, 2018, from https://www.press.umich.edu/6715/institutions and economic theory

7. Ofìcìjnij sajt Deržavnoï službi statistiki Ukraïni. Zovnišn'oekonomična diâl'nìst'. (2018). Retrieved October 25, 2018, from http://www.ukrstat.gov.ua/

8. Podatkovij kodeks Ukraïni vìd 01.10.2013 r. № 2755-XVII. (2018). Retrieved October 26, 2018, from http://zakon2.rada.gov.ua/laws/show/2755-17

9. Rinok zerna Ukraïni: Vìd eksportu sirovini do gotovoï produkciï. (2017). Retrieved October 26, 2018, from https://agronews.ua/node/82481

10. Tkachenko, S. (2010). Obogaŝenie muki mikronutrientami na mel'nice. Hranenie I Pererabotka Zerna, (4 (130)), 15-17.

11. Položennâ pro Departament prodovol'stva Mìnìsterstva agrarnoï politiki ta prodovol'stva Ukraïni: Zatverdženo Nakazom Mìnìsterstva agrarnoï politiki ta prodovol'stva Ukraïni № 310 vìd 03.08.2015 r. (2018). Retrieved October 25, 2018, from http://minagro.gov.ua/ministry?nid=3010

12. Ofìijnij sajt PAT «Deržavna prodovol'čo-zernova korporaciâ Ukraïni». Retrieved October 25, 2018, from http://www.pzcu.gov.ua/ua/about

13. Nikishyna, O. V. (2017). Methodical approach to the evaluation the of integrated commodity market (pp. 1-89, Rep.). Saarbrucken: LAMBERT Academic Publishing.

Received 30 October 2018

Approved 14 November 2018

Available in Internet 29.12.2018

Цитування згідно ДСТУ 8302:2015

Нікішина О. В., Муратов О.М. Заходи подолання інституційних дисбалансів зовнішньоекономічної інтеграції українського ринку борошномельно-круп'яної продукції // Економіка харчової промисловості. 2018. Т.10, вип. 4. C. 29-38. doi: 10.15673/fie.v10i4.1130

Cite as APA style citation

Nikishyna O., \& Muratov O. (2018). Measures to overcome institutional imbalances of foreign economic integration of Ukrainian market of flour-grinding and cereal products. Food Industry Economics, 10(4), 29-38;

doi: $10.15673 /$ fie.v10i4.1130 